Триколенко Софія Тарасівна, https://orcid.org-0000-0003-2766-8345

кандидат мистецтвознавства, Наиіональний авіаційний університет Київ, Украӥна baronessainred@gothic.com.ua

\title{
СЦЕНОГРАФІЧНА МЕТАФОРА НА ТЛІ ІЛЮСТРАТИВНОГО НАТУРАЛІЗМУ
}

Метою дослідження $є$ розгляд принципів залучення метафоричних елементів до вистав камерної сцени, декораційне оформлення яких загалом відноситься до натуралістично-ілюстративної тенденції. Методи дослідження поєднують спостережний та аналітичний огляди принципів формування сценографічного середовища, забезпечуючи дослідження сценографічної метафори на тлі ілюстративного матеріалу. Наукова новизна стаття полягає у розкритті особливостей залучення елементів метафори до загалом натуралістично-ілюстративного сценографічного оформлення. На прикладах вистав київського камерного театру «Срібний острів» розглянуто прийоми введення до спектаклю знакових, символічних деталей, які посилюють емоційний фон мізансцен та вибудовують в уяві глядачів певний асоціативний ряд. Для дослідження обрано три принципово різні вистави: драма, дитяча казка, комедія. Класифіковано сценографічні модулі, які можуть бути задіяні і протягом усієї вистави, і в певний момент. Висновки. На основі аналізу вистав театру «Срібний острів» стверджується, що для камерної сцени прийом залучення метафоризації до загального натуралістично-ілюстративного рішення дає змогу подати i класичну, i сучасну драматургію актуально й цікаво для сучасного глядача.

Ключові слова: сценографія; театр; вистава; камерна сцена; постановка; декорація; метафора.

Триколенко София Тарасовна, кандидат искусствоведения, Национальный авиаџионныій университет, Киев, Украина

Сценографическая метафора на фоне иллюстративного натурализма

Целью исследования является рассмотрение принципов привлечения метафорических элементов в спектакли камерной сцены, декорационное оформление которых в общем относится к натуралистическо-иллюстративной тенденции. Методы исследования сочетают наблюдательный и аналитический обзор принципов формирования сценографического среды, обеспечивая 
исследование сценографической метафоры на фоне иллюстративного материала. Научная новизна статьи заключается в раскрытии особенностей привлечения элементов метафоры в натуралистически-иллюстративное сценографическое оформление. На примерах спектаклей киевского камерного театра «Серебряный остров» рассмотрены приемы введения в спектакль знаковых, символических деталей, которые усиливают эмоциональный фон мизансцен и выстраивают в воображении зрителей определенный ассоциативный ряд. Для исследования выбраны три принципиально разные постановки: драма, детская сказка, комедия. Классифицировано сценографические модули, которые могут быть задействованы как в течение всего спектакля, так и в определенный момент. Выводы. На основании анализа постановок театра «Серебряный остров» утверждается, что для камерной сцены прием привлечения метафоризации в общее натуралистическо-иллюстративное решение дает возможность подать и классическую, и современную драматургию актуально и интересно для современного зрителя.

Ключевые слова: сценография; театр; спектакль; камерная сцена; постановка; декорации; метафора.

Trykolenko Sofia, Ph.D. in History of Arts, National Aviation University, Kyiv, Ukraine

\section{Scenography metaphor on the background of illustrative naturalism}

The purpose of the article is to study the principles of attracting metaphorical elements to the performances of the chamber scene, whose decorative design is generally related to the naturalistic and illustrative tendencies. Methodology of investigation consists in observational and analytical review of the formation of the scenario principles environment providing a study of scenic metaphor on the background of illustrative material. Scientific novelty of work consists in revealing the features of the metaphor's attracting elements to the general naturalistic and illustrative scenographer design. On the examples of the performances in Kyiv Chamber Theater "Silver Island", techniques are represented for introducing into the play of iconic, symbolic details that enhance the emotional background of the mise-en-scenes and build a certain associative series in the imagination of viewers. Three distinctly different performances have been chosen for the study: drama, children's fairy tale, comedy. There have been classified scenographer modules that can be used both during the entire performance and at some point. Conclusions. Having considered the plays of the theater "Silver Island", it can be safely asserted that for reception of the chamber scene the attraction of metaphorization to the general naturalistic illustrative decision and it gives 
an opportunity to present both classical and contemporary dramatically, actual and interesting for the modern viewer.

Key words: scenography; theater; performance; chamber scene; production; stage; metaphor.

Постановка проблеми. Нині можна виділити такі три основні тенденції сценографії: натуралістично-ілюстративна, яка базується на реалістичності передачі середовища; натуралістично-ілюстративна 3 елементами метафори; повністю метафоризована, що грунтується на створенні знакових асоціативних декораційних модулів, котрі розкривають заданий сюжет. Дослідження застосовуваних художниками прийомів у межах названих тенденцій сьогодні становить для мистецтвознавців важливе наукове завдання. Найпоширенішою в театрах усіх типів $є$ тенденція поєднання натуралістично-ілюстративного середовища $з$ елементами метафори, яке найвиразніше проявляється у виставах камерної сцени. Саме вивчення художніх прийомів залучення символічних, умовних деталей у реалістичну подачу ігрового середовища i $\epsilon$ науковою проблематикою цієї статті.

Аналіз останніх досліджень і публікацій. Питанням дослідження сучасного театротворчого процесу в Україні присвячені численні наукові розвідки, рецензії і критичні відгуки на сторінках друкованих видань та електронних ресурсів. Варто зазначити, що чи не найпотужніший пласт теоретичного матеріалу можна знайти саме в мережі Інтернет, де дослідники й театральні критики викладають незаангажовані та позбавлені кон'юнктури погляди на театральні дійства. Серед науковців, які звертаються до тематики сучасного українського театру, потрібно виокремити О. Островерх, Н. Владімірову, О. Клековкіна, Г. Веселовську та автора цієї публікації. Зокрема, О. Островерх і С. Триколенко приділяють значну увагу саме сценографії вистав, аналізуючи особливості художніх рішень. Натомість Г. Веселовська та Н. Владімірова розглядають режисерські інтерпретації класичних репертуарних творів, а також звертаються до нюансів акторської гри. О. Клековкін аналізує сучасні театротворчі процеси на тлі історичних, проводячи структурні паралелі між відомими спектаклями попередніх періодів і сучасними постановками.

Мета статті - розглянути принципи залучення метафоричних елементів до вистав камерної сцени, декораційне оформлення яких в цілому відноситься до натуралістично-ілюстративної тенденції.

Виклад основного матеріалу. У сценографічних концепціях оформлення вистав сучасного репертуару простежується тенденція виокремлення поєднання натуралістичних і метафоричних елементів, котра нині стала найпопулярнішою 
на сценах усіх типів. Для сценографічного рішення створюються модулі, що позначають певні елементи художнього рішення: реалістичні або метафоризовані декорації займають певний простір; вони (і великі, і дрібні) поділяються на епізодичні, тимчасові й постійні. Епізодичні виникають у певний момент, доповнюючи емоційне тло обраної мізансцени, зникають по іії завершенні; тимчасові перебувають на сцені певний час, змінюючись відповідно до сюжетного повороту; постійні перебувають у видимому просторі сцени весь час, проте можуть змінювати своє положення. Порівнюючи ступінь застосування знакових, образних елементів різних вистав, можна визначити основні параметри використання метафоричних модулів. Значна кількість символіки зосереджена і в оформленні конструктивних дійових елементів, однак серед багатьох вистав додаткові модульні деталі відділені від загальних декорацій. Зокрема, слід зауважити, що у виставах великої сцени місцем зосередження метафоричних модулів часто є верхня площина сцени, яка для акторської гри безпосередньо не задіяна, проте концентрує значну увагу глядачів з огляду на розміщення у просторі.

Показовим прикладом оформлення можуть слугувати вистави камерного київського театру «Срібний острів», у репертуарі якого спектаклі класичних та сучасних авторів. «Срібний острів» - приватний театр, створений заслуженою артисткою України Людмилою Лимар у 1997 р., нещодавно відсвяткував 20-річний ювілей. Протягом своєї історії «Срібний острів» змінив чимало ігрових майданчиків, більшість його вистав розроблені для камерної сцени. Особливу увагу режисери театру приділяють емоційно-насиченим, психологічно-складним п'єсам, які дають змогу втілити найконтрастніші ситуації 3 людського життя, акцентувати увагу на актуальних для сьогоднішнього суспільства питаннях.

Пошук порозуміння, прощення, взаємної поваги та любові між близькими людьми в усі часи був одним із найактуальніших питань, що знаходили висвітлення в творах усіх видів мистецтва. У сучасному світі, сповненому численних соціальних потрясінь, осмислення людьми межі добра і зла стало надзвичайно розмитим, адже кожна група та навіть окрема людська істота має свої морально-етичні критерії.

Спроби викрити, класифікувати людські вади відображаються у творах мистецтва, зокрема, у театрі. Відтворення родинних стосунків на тлі загальносуспільних процесів, пошук спільних інтересів, спокута давніх провин лягли в основу творчості одного з найзатребуваніших драматургів сучасності Мартіна Макдонаха, п’єси якого нині ставляться на сценах різних театрів світу. У 2016 р. театром «Срібний острів» було здійснено постановку спектаклю за п’єсою «Сиротливий Захід», яка отримала назву «Брати». Символічним стало 
те, що прем'єрою цієї вистави ознаменувалося відродження театру, що кілька років був закритим через відсутність приміщення. Засновник та художній керівник «Срібного острова» Л. Лимар, яка стала режисером вистави, прокоментувала свій вибір саме цієї п’єси як «пошук світла, добра в кожній особистості, розкриття братньої любові, сильнішої за образи й провини».

Дія п’єси відбувається в Ірландії, у провінційному містечку Лінен на острові Коннемара. Сюжет розкриває непрості стосунки між двома братами, які нещодавно поховали батька, - Коулманом та Валеном, який через невідомі на початку дії причини став єдиним спадкоємцем, чим безупинно дражнить Коулмана. Спроби священика Уолша примирити братів щоразу зазнають фіаско, проте він будь-що прагне «врятувати їхні душі» і навіть життя, адже вони цілком здатні вбити один одного. Паралельно розвивається ще одна сюжетна лінія, що є своєрідним відображенням стосунків між братами: юна краля Гелін, донька місцевого самогонного «магната», закохується у священика, проте іiї поведінка радше відштовхує його, ніж приваблює. Ситуативний ряд розкриває всю огиду сприйняття місцевими мешканцями людських трагедій, які давно не знають ані співчуття, ані спокути, ані прощення: переслідуючи власну вигоду, мешканці міста здійснюють злочини, про які всі знають, проте залишаються осторонь. Священика найбільше шокує той факт, що злочинці навіть не думають сповідатися у своїх гріхах, вважаючи їх необхідними «сходинками» для досягнення мети. Потрібно зазначити, що ця п’єса належить до Коннемарської трилогії; у ній згадуються події двох інших п’єс із цієї серії - «Королева краси» та «Череп з Коннемара». Постать отця Уолша є своєрідним спільним сегментом, котрий об'єднує всі історії: у п’єсі «Сиротливий Захід» він виступає самостійним персонажем, існуючи безпосередньо на сцені, а не лише в діалогах інших героїв. Саме він бере на себе місію примирення братів, що, з огляду на його духовний сан, $\epsilon$ цілком зрозумілим кроком, але суперечить тому факту, що він знає про співучасть братів у вбивстві їхнього батька. Активна соціальна позиція, громадська i виховна робота постійно занурюють Уолша у вир місцевих конфліктів та їхніх кримінальних наслідків, що призводить до розчарування у своєму духовному покликанні; проте усвідомлення кровного зв'язку між Коулманом та Валеном спонукає його до боротьби за їхні душі (Триколенко, 2017).

Відверта чорнушність та побутовість сюжету в театральній обробці Л. Лимар трансформується у глибоко філософську, гостросоціальну драму, що викриває людські вади, вказуючи шлях до спокути. Інтерпретація образів персонажів фокусує увагу на їхні спільні риси та життєві інтереси, через які уможливлюється пошук взаєморозуміння. 
Сценографічне оформлення, розроблене С. Триколенко, базується на використанні обумовлених текстом предметів побуту; у загальну ілюстративність декораційного оформлення вносяться елементи метафори, символіки, які видозмінюють ігровий простір та виносять дію за територіальночасові межі, надаюючи проблематиці загальнолюдського змісту. Загалом реалістично-ілюстративний інтер'єр будинку, в якому мешкають брати, демонструє невибагливий міщанський смак: родинні фото на стінах, типове для католиків розп'яття над імпровізованим вівтарем, постери 3 оголеними жінками, грубі меблі. Все здається до банальності буденним, проте відчуття сірості зникає завдяки введенню кольорового освітлення. Алкоголічний екстаз виводиться на новий емоційний рівень та здається божевільним, гіперболізованим, а навколишній інтер'єр заглиблюється в марення та абсурд. Активно використовуються спецефекти: за сюжетом вистави, чимало конфліктів відбуваються через новеньку пічку Валена, тому періодично сцена потопає в задимленні. Єдиний епізод поза межами будинку відбувається на березі озера, в якому на початку спектаклю втопився Том Хенлон. Для оформлення мізансцени використовується епізодична метафорична декорація у вигляді завіси, яка виконує функцію ілюстрування місця дії та розмежування ігрової зони. Діалог Уолша і Гелін проходить на тлі великої напівпрозорої зеленої завіси з вишитими водоростями, яка частково прикриває інтер'єр у глибині сцени. У таким спосіб виникає асоціативне трактування діалогу: якою б мальовничою не була природа та чистими почуття Гелін, побутові проблеми та аморальність мешканців містечка невіддільні від них. Освітлення сконцентроване на передньому плані, де відбувається дія.

Осмислення заданої проблематики ірландського автора українськими постановниками привело до появи емоційно потужного, актуального для сьогодення спектаклю, що не має чіткої географічної прив'язки: він змушує глядачів замислитися над власними провинами, усвідомити певну подібність до героїв вистави і знайти шлях до єднання із близькими.

Дитячий спектакль «Чарівна лампа Аладіна» в постановці Ю. Раєвського поєднує образно-символічні елементи із загальним натуралістичноілюстративним рішенням. Спрямованість вистави на дитячу аудиторію спонукала авторів до пошуку художньої концепції, яка б відразу проводила асоціативну паралель із відомими, певною мірою шаблонними ілюстраціями до східних казок. Декораційне рішення належить О. Татарінову, згодом воно було доопрацьоване С. Триколенко. Спостерігається два основні модулі: масштабні мавританські арки з обох боків сцени, які позначають входи і виходи ігрового простору, та велике стилізоване шатро, котре змінює свою змістовну функцію. Передній план акцентовано східним килимом, на якому відбуваються 
певні мізансцени. Права куліса оформлена великим декоративним панно із графічним пейзажем казкового Багдада.

Привертає увагу ігрова трансформація декорацій під час дії: актори самі переставляють елементи оформлення, видозмінюючи сценічне середовище. Цей режисерський хід зумовлений особливостями камерного простору: для більшості невеликих сценічних майданчиків неможливо задіяти звичну для великих сцен машинерію, а отже, доводиться використовувати доступні засоби. Втім, у цій ситуації ігрова акторська зміна декорацій додає спектаклю живої енергії, а маленьким глядачам - відчуття занурення в події.

Зокрема, дія першої картини розпочинається на базарі, де перетинаються шляхи героїв казки: там Аладін знайомиться із принцесою Будур, там же візир Джафар зі своєю прислужницею Іфриткою обговорюють план захоплення влади. На сцені базар переданий за допомогою великої ширми із крамом, що відмежовує задник сцени. Із-за неї з'являється Джин, коли Аладін випадково тре лампу. Освітлення концентрує увагу глядача на передньому плані, натомість глибина потопає в пітьмі. Коли події казки переносяться до палацу, ширму прибирають, і перед глядачем постає освітлене шатро, під яким облаштовані султанські покої. На його тлі розігруються наступні мізансцени; подальші трансформації ігрової площини відбуваються лише за допомогою гри освітлення.

У цьому зв'язку варто докладніше зупинитися на технічних особливостях оформлення: в орнаментах ширм використано флуоресцентні фарби, завдяки чому частина розписів світиться в ультрафіолетовому світлі, як і деталі шатра. Зміни освітлення виділяють епізодичну метафоризовану декорацію, що прихована за звичайними статичними конструкціями, завдяки чому посилюється казкова атмосфера вистави. Як бачимо, на прикладі дитячої вистави можна з'ясувати особливості поєднання реалістичних метафоричних елементів, котрі становлять єдину гармонійну концепцію.

Для вистави «Дамський кравець» за твором Ж. Фейдо режисерпостановник Л. Лимар розробила сценографічне рішення, яке, грунтуючись на принципах натуралістичної ілюстрації, включає численні метафоричні деталі. Легкий водевільний настрій постановки сформував певні вимоги до сценографічного оформлення: яскраві елементи декору ширм, що розмежовують сценічний простір, манекени у строкатих сукнях, розкішні дамські костюми, - усе повинно працювати на підняття настрою, інтриганську співчутливість проблемам головного героя.

За сюжетом, головний герой - лікар Муліно - опинився у скрутній ситуації: він намагається приховати від дружини візит до коханки, прикриваючись хворобою друга Бассіне. Але «помираючий» друг раптово 
приходить у гості, а за ним слідом - коханка зі своїм чоловіком. Переляканий Муліно змушений видати себе за кравця, і потім зняти у Бассіне квартиру кравчині, яка нещодавно вибралася. Отже, брехня нагромаджується одна на одну, створюючи складний, абсурдний любовний багатокутник.

Основні декорації встановлені стаціонарно, оскільки немає можливості задіяти машинерію. Їхні окремі елементи рухають актори під час дії: квартира Муліно перетворюється на квартиру кравчині, і навпаки. Ошатно вдягнені манекени постають перед глядачами, немов мовчазні свідки людських вад. Їх можна трактувати як ілюстративний матеріал, що доповнює квартиру кравчині, або як метафоризовані образи жіночої легковажності та численних любовних перемог Муліно. В деяких мізансценах вони стають повноцінними учасниками дії, вступаючи в «діалоги» 3 акторами.

Образно-символічне значення манекенів підкреслене постійним зверненням до тематики дамського вбрання як символу мінливості та спокуси. Взаємодія акторів із манекенами акцентує увагу на завуальованій проблематиці вистави: відсутність порозуміння між подружжями, обмани, переховування. Їхні шлюби тримаються на принциповому небажанні одного партнера бачити зради іншого. Так само, як манекени не звертають увагу на відвідувачів ательє або магазинів, так і половина персонажів не бажає бачити обману. Неабияке значення має освітлення: воно не лише демонструє зміну місця дії, а й підкреслює емоційні перепади.

Цю виставу можна розглядати в контексті натуралістичноілюстративного середовища, у той же час варто зосередити увагу на постатях манекенів як образно-символічних, метафоричних елементів. Вони не лише доповнюють інтер'єр, а й несуть важливу змістовно-філософську функцію. Їх використання у виставі - тимчасове, проте вони задіяні саме в найпотужніших кульмінаційних мізансценах.

Новизна дослідження визначається розкриттям особливостей залучення елементів метафори до загалом натуралістично-ілюстративного сценографічного оформлення. Розгляд вистав київського камерного театру «Срібний острів» (для дослідження обрано три принципово різні вистави: драма, дитяча казка, комедія) сприяв з'ясуванню прийомів увведення до спектаклю знакових, символічних деталей, які посилюють емоційний фон мізансцен та вибудовують в уяві глядачів певний асоціативний ряд. Класифіковано сценографічні модулі, які можуть бути задіяні і протягом всієї вистави, і в певний момент.

Висновки. Розглянувши вистави театру «Срібний острів», можна стверджувати, що для камерної сцени прийом залучення метафоризації до загального натуралістично-ілюстративного рішення дає можливість подати i класичну, і сучасну драматургію актуально й цікаво для сучасного глядача. 
При цьому потрібно створити характерні візуальні образи, які відразу сформують потрібний асоціативний ряд. У цьому зв'язку варто процитувати знаменитого художника-сценографа М. Френкеля: «Вирішити спектакль, звісно ж, завжди слід по-своєму, по-новому. Сучасно. Так, щоб проблеми, викриті автором п'єси, схвилювали сьогоднішнього глядача, змусили його задуматися над реальністю, змусили до прагнення покращити світ. Оновлений актуальним звучанням зміст класики або своєрідне прочитання сучасної п'єси будуть пов'язані з новою, оригінальною формою вистави» (1980, с. 7).

Сучасні театральні та шоу-постановки складають потужний пласт новітньої культури, яка потребує серйозного мистецтвознавчого дослідження. Звернення до тематики сценографії, зокрема їі сучасних візуально-виражальних засобів, становить важливу тему для теоретичних праць. Теоретичною базою для грунтовних висновків стосовно сучасних процесів можна вважати мистецтвознавчі та історіографічні надбання попередніх періодів, а також художню критику. Для майбутніх досліджень тема вивчення прийомів сучасного мистецтва театральної сценографії залишається однією з найбільш актуальних у царині театрального мистецтва.

\section{Бібліографічні посилання}

1. Триколенко С. Т. «Брати» на Срібному острові. Все про мистецтво. 2017. URL: http://artlis.blogspot.com/p/blog-page_21.html. (дата звернення: 08.03.2018)

2. Френкель М. Современная сценография: Некоторые вопросы теории и практики. Киев : Мистецтво, 1980. 131 с.

\section{References}

1. Trykolenko S.T. (2017). '«Brothers» on the Silver Island'. Vse pro mystetstvo [All about art.], [online] Available at: 〈http://artlis.blogspot.com/p/blog-page_21.html> [Accessed 8 March 2018].

2. Frenkel' M. (1980). Modern scenography: Some theory and practice issues. Kyiv: Mystetstvo.

(C) Триколенко С. Т., 2018

Стаття надійила до редакиії 24.02.2018 